CORRIGENDUM

\title{
Breaking barriers to novel analgesic drug development
}

Ajay S. Yekkirala, David P. Roberson, Bruce P. Bean \& Clifford J. Woolf

Nature Reviews Drug Discovery 16, 545-564 (2017)

The compounds APD371,LY2828360, S-777469 and KHK6188 were incorrectly referred to as inhibitors of the cannabinoid receptors CB1 and CB2 in Table 1, when they are cannabinoid receptor agonists. In addition, KHK6188 is not currently in a Phase 2 clinical trial for neuropathic pain as stated in Table 1 and development of this agent has been discontinued. The error has been corrected in the html and pdf versions online. 